\title{
People power against climate change
}

\section{Local government and communities needn't wait for the big players to decide on action.}

Sir - Your Editorial “Carbon impacts made visible” (Nature 429, 1; 2004) mentions two bottom-up opportunities that need to be seized if we are to reduce the causes of climate change. But you omitted another, possibly more significant, one that is already happening.

Since 1993, local governments in towns, cities and municipalities around the world have been signing up to their own Kyoto-like commitments, largely as part of the International Council for Local Environmental Initiatives programme, "Cities for Climate Protection" (www.iclei. org). At the last count, almost 600 had signed up. In the United Kingdom, 60 towns and cities, including Middlesbrough, have signed up to a similar programme, under the Nottingham Declaration on Climate Change. Added together, these communities produce nearly $10 \%$ of the world's greenhouse gas emissions. So these community-level targets should not be ignored.

Local governments are well placed to get to the nub of the problem in a way that global treaties and carbon trading can never achieve. They can get the message across to the residents, shopkeepers and drivers of the world that efficient, cheapto-run homes, fridges, cars and so on can improve their quality of life while helping a global cause. Also, people can take action locally regardless of national priorities: witness the wealth of climate-friendly activities going on in many US cities despite the now infamous anti-Kyoto stance of the Bush administration (see Earthed 9-11, May 2004).

So in an age when the power of communities seems to be shrinking against the might of world governments and multinationals, it's refreshing to see that bottom-up local action still has an important part to play in tackling climate change. Power to the people indeed!

\section{Jim Gillon}

Community Protection Service,

Middlesbrough Council, PO Box 65,

Vancouver House, Central Mews,

Gurney Street, Middlesbrough TS1 1QP, UK

\section{Ground rules for dealing with anthropomorphism}

Sir-Clive Wynne misrepresented my published views in his Concepts essay "The perils of anthropomorphism" (Nature 428, 606; 2004). The concept of 'critical anthropomorphism' helps to establish ground rules for dealing with the inevitable anthropomorphic tendencies that we, as sentient human beings, confront in trying to understand the behaviour of other species.

Critical anthropomorphism involves not only careful replicable observation, but also knowledge of the natural history, ecology, and sensory and neural systems of animals as well. Such knowledge itself changes and has led me to reinterpret examples of animal behaviour involving, for example, perception and cooperation, in my own research. Problems can also arise when scientists fail to recognize inadvertent anthropomorphism in 'objective' studies; colleagues and I have documented erroneous conclusions in areas as diverse as communication, foraging, conservation planning and zoo design. As noted in your News Feature “True colours" (Nature 428, 596; 2004), "It's only when you begin to see the world as birds do - detecting light in the ultraviolet spectrum - that the full subtlety of their behaviour is revealed."

Wynne asserts that I use critical anthropomorphism to argue that deathfeigning behaviour in snakes is best understood by assuming that animals have conscious states. What we have shown is that hognose snakes monitor their visual environment and make adaptive decisions enabling escape behaviour while appearing completely unresponsive, and thus they are not unaware or unconscious of their surroundings when in this state, as previous authors had assumed. This problem with the word "conscious" is why I have argued for use of the term "private experience" (derived from behaviourist B. F. Skinner's "private events") and not "consciousness" in the study of animal behaviour. The issues here are controversial enough to make careful attention to language essential.

\section{Gordon M. Burghardt}

Department of Psychology and Ecology \& Evolutionary Biology, University of Tennessee, Knoxville, Tennessee 37996, USA

\section{Political interference not needed in Iraqi science}

Sir - Your News story on the assassination of scientists in Iraq, "Iraqi killings prompt calls for US to evacuate weapons scientists" (Nature 429, 115; 2004), included the statement that, according to officials at the US Department of State, "scientists felt excluded from an attempt by a largely expatriate group of Iraqi researchers to form an Iraqi academy of science".

In fact, the meeting to formally establish the Iraqi National Academy of Science, held at the Royal Society in London in November 2003 with the participation of the French and US national science academies, involved 12 scientists and engineers, eight of whom are - and for many difficult years have been - based in Iraq.

It is disappointing that such a carelessly inaccurate allegation should be attributable to the US Department of State. Indeed, there is a danger that it may be misinterpreted as a politically motivated attempt to undermine the new Iraqi academy. Iraqi science needs an independent academy "promoting pure and applied science for the service of the people and the country, and reviving Iraqi talents for the good of humanity", as its charter states. It does not need political interference from within or outside Iraq. Robert May

The Royal Society, 6-9 Carlton House Terrace, London SWIY 5AG, UK

\section{No joke when a technical fault fools readers}

Sir - I was sent a message from Nature offering a free electronic version of the 1 April 2004 issue that could be downloaded. Although I carefully followed the instructions I was not able to get access to it online. When I tried again I was refused access because only one copy was allowed and it had a record of my previous abortive attempt. When I reported this to the Nature customer-support staff I was informed that the free issue was no longer available. Was the free copy ever available? Or was it all an April Fool joke?

Michael Heather

Law School, Northumbria University, Ellison Place, Newcastle upon Tyne NE1 8ST, UK

The 1 April issue of Nature, available for a limited time as a digital edition, was downloaded by almost 6,000 people from Newsstand, the third-party provider. However, a small number of people encountered some technical problems, which are being addressed by Newsstand (enquiries to support@newsstand.com). Nature apologizes for any inconvenience -Publisher, Nature 